\title{
Depresja i neoliberalny kapitalizm. Kilka uwag na marginesie Koali Lukasa Bärfussa
}

Paweł Piotr Jasnowski

TEKSTY DRUGIE 2019, NR 3, S. 283-304

DOI: 10.18318/td.2019.3.17 | ORCID: 0000-0001-7504-7055

Peut-on attendre que la masse extraordinaire de souffrance que produit un tel régime politico-économique soit un jour à l'origine d'un mouvement capable d'arrêter la course à l'abîme?'

Pierre Bourdieu

Mimo to jego porażka była niezaprzeczalna, tak, poniósł klęskę, ale im dłużej się nad tym zastanawiałem, tym bardziej narastało we mnie podejrzenie, że nie przegrał walki z samym sobą, ze swoimi wadami, lecz z większym, potężniejszym i przede wszystkim starszym przeciwnikiem. ( $\mathrm{K}^{2}$, s. 49-50)

Lukas Bärfuss

For as long as the mental health industry resides within a framework that speaks the language of self-hood, and

1 P. Bourdieu L'essence du néolibéralisme, "Le Monde Diplomatique" 1998 no. 528 , s. 3.

2 Skrótem K oznaczam cytaty z powieści: L. Bärfuss Koala, przeł. A. Żychliński, Ossolineum, Wrocław 2017. 
minimizes the importance of political and economic forces, it will continue to contribute to the problems that it has been charged with healing. ${ }^{3}$

Carl Walker

Die Dichter schaffen keine Orte, sie schaffen Räume, in denen sie sich selbst und wir alle uns verändern können, in der Vorstellung, und manchmal sogar in der Wirklichkeit. ${ }^{4}$

Lukas Bärfuss

\section{Pamięci Anny Walendowskiej}

D epresja jest obecnie uważana za jeden z najpoważniejszych problemów zdrowotnych w Europie i na świecie. Wszystko wskazuje na to, że krzywa zachorowań nie tylko nie spadnie, ale będzie stale i ostro wrastaćs. Równolegle rośnie wskaźnik samobójstw. Jak pokazuje WHO, od lat 6o. XX wieku do dziś nastąpił skok o ponad 60\%. Niedawny raport WHO był według słów dyrekcji: „apelem do podjęcia działań mających na celu rozwiązanie ogromnego problemu zdrowia publicznego, który stanowczo zbyt długo stanowił temat tabu"6. Jak pisze Carl Walker, rosnącej krzywej, w przypadku depresji, nie da się złożyć na karb usprawnionej (niepowątpiewalnie) zdolności diagnozy i większej (wielokrotnie) świadomości społecznej. Widmo epidemii, spostrzega ironicznie brytyjski badacz, zostawia więc często (także w akademii) wrażenie „wielkiej i złożonej zagadki naszych czasów”. Zdaniem Walkera

3 C. Walker Depression and Globalization The Politics of Mental Health in the 21st Century, Springer Science+Business Media, London 2008.

4 Cyt. za: A. Bartl Kleist und Ich. Eine Analyse der 15 Kleist-Preis-Reden 2000 bis 2014 , "Kleist-Jahrbuch $2016 "$ ", s. 33 .

5 Zob. choćby C. Walker Depression and Globalization...; „Whereas in 1990, depressive disorders were estimated to be the leading cause of disability and were the fourth leading cause of total global burden of disease; the World Health Organisation expect them to be the second leading cause of disease burden by $2020 "$ ", s. VII.

6 Zob. http://www.who.un.org.pl/aktualnosci.php?news=131\&wid=12\&wai=\&year=\&back=/.

7 "While this has undoubtedly been the case in recent years, there is little evidence to suggest that such an increase in the recognition of depression is accountable for the recent rise and the projected rise in the next few years", C. Walker Depression and Globalization..., s. 133.

8 "When we hear prominent public servants (and academics in the mental health field) talk of the growing problem of depression and mental health, they often do so as if it represents some impenetrable mystery, insolvable by some of the greatest minds", tamże, s. 156. 
jest to efekt myślenia depresji jako problemu z wnętrza podmiotu, wyrwania jednostki z kontekstów kulturowych, społecznych i politycznych. Podobnie rzecz ujmował Mark Fisher:

The dominant school of thought in psychiatry locates the origins of such 'beliefs' in malfunctioning brain chemistry, which are to be corrected by pharmaceuticals; psychoanalysis and forms of therapy influenced by it famously look for the roots of mental distress in family background, while Cognitive Behavioural Therapy is less interested in locating the source of negative beliefs than it is in simply replacing them with a set of positive stories. ${ }^{9}$

Oczywiście ani Fisher, ani Walker nie odrzucają całkowicie tych modeli wyjaśnień10 ${ }^{10}$ Raczej krytykują daleko posuniętą biologizację depresji, pomijanie roli środowiska, a zwłaszcza kontekstu społecznego i ekonomicznego". Dla autora Capitalist Realism oznacza to jej całkowite odpolitycznienie, a więc beztroską akceptację sytuacji, w której widmo epidemii depresji staje się coraz bardziej realne, a cierpienie nieznośne. Niedawny „The Guardian”, nie unikając słowa „epidemia”, pisał w tym kontekście: „nadszedł czas, by zapytać, dokąd zmierzamy i dlaczego"12. W głośnym eseju Mark Fisher zapytywał ,jak to możliwe, że akceptujemy fakt, iż taka masa ludzi, zwłaszcza

9 „Dominująca szkoła myślenia w psychiatrii lokalizuje źródła takich «przekonań» w wadliwie działającej chemii mózgu, która korygowana jest przez leki; psychoanaliza i formy terapii, na które ma ona wpływ, znane są z poszukiwania źródeł psychicznego cierpienia w historii rodzinnej, natomiast terapia poznawczo-behawioralna mniej zainteresowana jest lokalizowaniem źródła negatywnych przekonań, a bardziej po prostu zastąpieniem ich zestawem pozytywnych historii" - przekł. P.J. M. Fisher Good for Nothing, https://theoccupiedtimes.org/?p=12841 (3.03.2018). Za zwrócenie mi uwagi na piśmiennictwo Marka Fishera i inspirujące uwagi dziękuję w tym miejscu Kubie Kuleszy (www.kubakulesza.pl).

"While such biological perspectives are undoubtedly crucial in our greater understanding of mental illness, such a dominant focus on individual factors belies the fact that there are structural, economic and social conditions, especially under the current context of globalization, that play a role in the suffering of the mentally ill and their families", C. Walker Depression and Globalization..., s. 165. Zob. o tym także M. Fisher Capitalist realism: is there no alternative?, Zero Books, WinchesterWashington 2009. ardian", https://www.theguardian.com/commentisfree/2016/oct/12/neoliberalism-creatingloneliness-wrenching-society-apart (28.03.2018). 
młodych, choruje?"13. Podobnie George Monbiot pytał „Jakie może być większe oskarżenie systemu niż epidemia chorób psychicznych?"14. O jaki system dokładnie chodzi? Jak (dokładnie) miałby przekładać się na nasze zdrowie? Co o tym mówi nam współczesna literatura i wreszcie - jakie rozwiązania nam podsuwa? Na te właśnie pytania próbuję odpowiedzieć w niniejszym artykule, odwołując się do przełożonej niedawno na język polski powieści Lukasa Bärfussa Koala ${ }^{15}$.

\section{Literackie śledztwo}

W grudniu 2011 roku życie odebrał sobie przyrodni brat szwajcarskiego pisarza. W jego ojczyźnie dzień w dzień taką próbę podejmuje 40 osób; czterem się udaje. Samobójstwo, powiada jego alter ego, jest „powszechną śmiercią, pospolitą niczym krótkowzroczność” (K, s. 24). W Koali narrator także mierzy się z „nagłą” decyzją pół-brata. Tropi jego historię, próbując pojąć jego radykalną decyzję, rozwikłać zagadkę, którą zostawił. Bärfuss aranżuje „śledztwo”, które ma przynieść rozwiązanie, szybko jednak okazuje się, że tradycyjne narzędzia nie wystarczą, że trzeba odrzucić kompendia „sumiennych neurologów” („bezużyteczne dla wyjaśnienia [...] sytuacji, K, s. 33), by zamiast tego wyzyskać imaginację i literacką fikcję. Bez niej gest pół-brata pozostanie wielką i złożoną zagadką, jak w ironicznym komentarzu Walkera.

Zacznijmy jednak od początku. Narratora z bratem łączyły chłodne relacje, widywali się rzadko. Gdy zobaczyli się po raz ostatni w rodzinnym mieście, gdzie pisarz przyjechał na odczyt, brat na zorganizowanej kolacji zasiadł obok, zrezygnował z jedzenia. Unikał słów, szukał dystansu i tylko uprzejmość powstrzymywała go przed pożegnaniem (K, s. 9). Czytelnik dowiaduje się o nim niewiele. Pod koniec życia pracował w noclegowni. Przyjaciele, którzy odnaleźli go martwego, wspominali, że przed śmiercią był przygnębiony, ale nie niepokoiło ich to, wiedzieli bowiem, jak wiele przeszedł, znali jego nastroje (K, s.17).To jedyny powieściowy passus wskazujący na jego psychiczną udrękę. Śmierć brata nie daje narratorowi spokoju. Roztrząsanie przeszłości rzuca nieco światła na obu, niemających wiele wspólnego, braci. Podczas gdy jeden

13 M. Fisher Capitalist realism, s. 19.

G. Monbiot Neoliberalism is creating loneliness...

W artykule opieram się nade wszystko na Koali Lukasa Bärfussa, ale sięgam też pomocniczo po teksty innych autorów (m.in. Georges'a Pereca i Davida Szalay'a), które pozwalają mi w szerszym kontekście dostrzec podejmowane problemy. 
inwestuje, pożąda, dąży do celu, drugi odpuszcza ambicję i walkę. Narrator wiedzie „wzorcowe” życie (satysfakcjonująca praca, dom, żona, dzieci) i pławi się w skromnym, ale rozkosznym luksusie. Brat pragnie zaś tylko tego, co naprawdę konieczne. Jeden wyznacza sobie nowe cele i próbuje je zrealizować, drugi ceni ciszę i spokój - żadnego zgiełku, żadnych namiętności. Jego gesty żywo przypominają bohatera Georges'a Pereca (innego kronikarza żywotów abnegackich). Człowiek, który śpi, także odrzuca ciąły przesyt „słów, planów, wielkich przedsięwzięć"16

ten kocioł, piec, ruszt, jakim jest życie, te miliardy nakazów, zachęceń, ostrzeżeń, egzaltacji, rozpaczy, to morze przymusów bez końca, ta odwieczna maszyna, która produkuje, zgniata, pochłania, omija zasadzki i rozpoczyna od nowa, ten błogi terror, który chce rządzić każdym dniem, każdą godziną twojej marnej egzystencji [wyróż. -P.J.]. ${ }^{17}$

Ów nieznośny zgiełk, to dla niego nazbyt wygórowana cena za przynależność do rodzaju ludzkiego (człowieka zdefiniowanego przez współczesną kulturę). Bohater autora Rzeczy nie pnie się po kolejnych szczeblach kariery. Jak półbrat Bärfussa, chce czynić tylko to, co konieczne, „same gesty, a nie żadne dowody, nie moneta wymienna"18. Chce zapomnieć, co znaczy podejmować starania, odnosić sukcesy, być wytrwałym. Nie zależy mu na zwycięstwie, gdyż nie wie, co (ostatecznie) miałoby oznaczać. Zamiast tego pragnie zobojętnieć, sprawić, by nic nie miało nad nim władzy, stać się doskonale wolnym. Ścisły inwentarz jego mizernej fortuny daje się streścić w kilku słowach ${ }^{19}$. Niemal dokładnie tyle pozostawi po sobie bohater Koali. Na niewielkiej kartce papieru wyliczy cały swój dobytek i dokona jego podziału. Spojrzenie narratora (w pierwszej części powieści) jest bez reszty paternalistyczne. Brat nie mógł być szczęśliwy, myśli, skoro wiódł życie tak dalece odmienne od obiegowych kryteriów dobrego życia, skoro tak ostentacyjnie wyrzekł się ambicji, odwagi, siły i przebojowości (K, s. 38; s. 49). Brat ucieleśnia dla niego życie, którego człowiek współczesny winien unikać, ucieleśnia odwrotną stronę

\footnotetext{
16 G. Perec Człowiek, który śpi, przeł. A. Wasilewska, Lokator, Kraków 2011, s. 31.

17 Tamże.

18 Tamże, s. 47.

19 Tamże, s. 18.
} 
tego, co tworzy człowieka odpowiedzialnego. Jego stosunek do zmarłego jest więc ambiwalentny, może nawet niechętny („Musiałem zacząć nienawidzić brata", K, s. 35) - za jego irytującą bierność i programową bezużyteczność, którą odstawał od innych, i od niego samego.

Opresyjne spojrzenie narratora (pod którym obiekt, o ile nie ma dość sił, by stawić opór może tylko palić się ze wstydu), znajduje rozwinięcie w opowieści, w którą nieoczekiwanie przeistacza się powieść. Jak pamiętamy, śledztwo grzęźnie, tradycyjne narzędzia nie pozwalają na żadną prostą diagnozę, tym zaś co pchnie je naprzód, okazuje się imaginacja i fabulacja.

Właśnie imaginacji należało przypisać funkcję środka teoriopoznawczego do zrekonstruowania opowieści, na temat której brak było abstrakcyjnych pojęć, istniały tylko konkretne obrazy. Musiałem szukać [...] w pojedynczych znaleziskach z życia brata, w przypadkowym odłowie z jego egzystencji. (K, s. 51)

Wyjaśnienia, okazuje się, szukać trzeba, zestawiając ze sobą dwie historie, doprowadzając do krótkiego spięcia między nimi. Paternalistyczne spojrzenie narratora i postawa brata znajdują zaskakujące rozwinięcie w opowieści o kolonizacji Australii i eksterminacji pewnego gatunku torbaczy - koali. Czytelnik zostaje rzucony w historię, która, na pierwszy rzut oka, nie ma nic wspólnego z samobójstwem bohatera. Cóż bowiem mogą mieć wspólnego postrzępiona, pełna wyrw opowieść o bracie, z osobliwą historią koali, żyjącego gdzieś na końcu świata? Jeden i drugi tekst wydają się więc zrazu obce, uderzająco niezgodliwe. A jednak okazują się ze sobą nierozerwalnie splecione, jakby żaden nie mógł istnieć bez drugiego, jakby tylko dzięki ich spotkaniu, tylko dalekiemu światłu, jakie na siebie rzucają, mogło zostawić wyjawione to, czego nie ma w jednym i drugim tekście, lecz tylko na ich delikatnym, ulotnym przecięciu. Narrator i czytelnik odnajdą klucz do zagadki nie bezpośrednio, ale jakby w negatywie. Ów splot czytelnik uświadamia sobie za sprawą przezwiska, które nagle odpomina sobie narrator. Okazuje się, że jego brat otrzymał totem „koala”, który nadali mu koledzy z drużyny harcerskiej. Co więcej, staje się wyraźne, że cechy torbacza (jego bierność i skłonność do samotniczego trybu życia, zadowolenia się tym, co jest) odpowiadają cechom bohatera.

Spójrzmy, co właściwie mówi ów drugi nieoczekiwany tekst. Rozpoczyna się obrazem zwierzęcia, które żyło w spokoju, cierpliwe, ,, bez walk i wszelkiego pośpiechu" (K, s. 68). Nikt, czytamy, nie zwracał na nie uwagi, niczego nie 
chciał.,Zwierzę wtuliło się w tysiąclecia [...] dotrzymywało kroku wzrastaniu drzew - to była jego prędkość bez ambicji i bez pomysłu, jak mogłoby coś zmienić na swoją korzyść. Zwierzę nie pragnęło niczego poza spoglądaniem z gałęzi ku lasom i pozwalaniem duchowi na odpoczynek" (K, s. 68-69). Działo się tak póki nie przybyli myśliwi, i znacznie później - kolonizatorzy. Gdy ci ostatni ze wzgórza ogarniali wzorkiem równinę i widzieli przywiezione z Europy bydło, odczuwali z zadowoleniem, że „kultura europejska [...] dobrze się rozwijała" (K, s. 118). Nawet gdyby jeden z nich miał doznać porażki, mówili sobie, „to bydło mnożyło się, wzięło sobie ten kraj w posiadanie” (tamże). Dla Europejczyków, którym udało się w końcu przekroczyć Góry Błękitne, świat, który zastali, miał małą wartość, w ich spojrzeniu był produktem izolacji. Lokalne rośliny i zwierzęta rodziły tyleż fascynacje, co wstręt:

Co niby mogło być dobrego w znoszących jaja ssakach, w podskakujących kreaturach z groteskowymi sprężynującymi kończynami czy w tych wyłupiastookich, ślamazarnych is to ta ch bez właści wości, które nie dysponowały żadną szczególną umiejętnością [wyróż - P.J.], zwisały na drzewach równie popielato, jak otępiale i głupio, zbyt leniwe, żeby uciekać - po cóż innego Pan miałby je stworzyć, jeśli nie w celu zebrania porządnej skóry? (K, s.140)

Ówczesny angielski badacz, wziąwszy pod uwagę fizjonomię i tryb życia koali, zapytywał „w jakimże celu wielki autor natury mógł stworzyć tego rodzaju istotę" (K, s. 132). Kolonizatorzy nie umieli znaleźć innego celu ich egzystencji - wyłącznie ściąganie przez uszy futra. Było dla nich „zgodne $\mathrm{z}$ wolą Bożą, gdy zastępowali te niższe organizmy, te pełzające stworzenia, efektami ho d owli cywiliz a cy j ny ch" (K, s. 140, wyróż. - P.J.)

Uruchamiając wspomnianą grę świateł, Bärfuss chce nam powiedzieć, że zarówno koala, jak i pół-brat są ofiarami kolonialnej przemocy. Tyle że w przypadku brata (naszym) „pewne mechanizmy cywilizacyjne - pisze Grzegorz Jankowicz - działają dziś subtelniej [...]. Niektóre z nich przeszły w stan utajnienia, inne zostały przez nas uwewnętrznione, dzięki czemu tym skuteczniej determinują nasz sposób istnienia"20. O jaki rodzaj mechanizmu i przemocy chodzi? 


\section{Ciemna strona kultury przedsiębiorczości}

W swym głośnym eseju niemiecki filozof Byung Chul-Han powiada, że nie żyjemy już dziś w społeczeństwach dyscypliny, ale aktywności, zaś ich mieszkańcem nie jest już podmiot posłuszeństwa, lecz Leistungssubjekt (podmiot osiągnięć). Jeśli pierwsze określała kiedyś negatywność zakazu (fraza „nie wolno"), to frazą drugiego jest nieograniczone „móc” („Yes, we can”) 21. Zakaz, nakaz i regułę zastępuje projekt, inicjatywa, motywacja („Fitter, happier, more productive") ${ }^{22}$.Ten, jak pisze Chul-Chan, pozytywny schemat możliwości jest dużo bardziej wydajny niż negatywność powinności. Szybszy i bardziej produktywny jest więc podmiot osiągnięć. Jak jednak zaznacza filozof, „Możliwość nie unieważnia [...] powinności. Podmiot osiągnięć pozostaje wciąż zdyscyplinowany, tyle że stadium dyscyplinarne ma już za sobą. Jest tak dlatego, że sam staje się swym opresorem, katem i ofiarą - sam nakłada na siebie jarzmo dyscypliny. Jego wolność (której jest pewien jak niczego innego) okazuje się rojeniem. W chwili, gdy internalizuje imperatyw bycia aktywnym, traci ją, a raczej stapia wolność z przymusem, „ulega wolności przymuszającej czy raczej wolnemu przymusowi maksymalizacji osiągnięćc"23.

Podmiot osiągnięć to menadżer, przedsiębiorca-samego-siebie, będący „swym własnym kapitałem, swym własnym producentem i źródłem dochodu"24. Walka o maksymalną wydajność nie jest dziś wyłączną cechą bankierów inwestycyjnych ${ }^{25}$. Przeciwnie, przedsiębiorczości (także w sferze społecznej, osobistej itd.) wymaga się od każdego; „każdy ma działać tak, jakby był właścicielem firmy - «przedsiębiorstwa-siebie»" ${ }^{26}$, przerobić swe ja na unowocześniony biznes. Renata Salecl, słoweńska filozofka, wskazuje tu na zachętę do działania jak korporacje: „powinniśmy, powiada, postawić sobie cele na całe życie, podejmować długoterminowe działania ekonomiczne, być elastyczni, powinniśmy restrukturyzować przedsiębiorstwo naszego

\footnotetext{
B. Chul-Han Społeczeństwo zmęczenia, przeł. M. Sutowski, „Krytyka Polityczna” 2017 nr 45, s. 43.

Radiohead Fitter, happier, more productive, z albumu: Ok Computer, Parlophone Capitol, 1997. Fraza ta miała rozmaite także fabularne wcielenia. W Zwale Sławomira Shutego jest to np. "szybciej, wyżej, lepiej" (tegoż, Zwał, W.A.B., Warszawa 2004, S. 109).
}

B.-Ch. Han Społeczeństwo zmęczenia, s. 45.

M. Foucault Narodziny biopolityki, przeł. M. Herer, PWN, Warszawa 2011, s. 231.

C. Cenderström, A. Spicer Pętla dobrego samopoczucia, przeł. Ł. Żurek, PWN, Warszawa 2016, s. 38.

A. Szarecki Kapitalizm somatyczny. Ciało i władza w kulturze korporacyjnej, Drugie, Warszawa 2017 , s. 243. 
życia i podejmować ryzyko konieczne dla zwiększenia zysków"27. Chodzi o zarządzanie sobą, patrzenie na siebie jak na produkt, promowanie, budowanie swej marki, kontrolowanie, jak kontroluje się biznes ${ }^{28}$.W ramach nowej formuły kapitalizmu ${ }^{29}$ suweren-samego-siebie winien łączyć takie cechy jak uroda i inteligencja, pewność siebie i odwaga, kreatywność i inicjatywa, wytrwałość i odporność na stres, optymizm i determinacja, poczucie taktu, urok osobisty ${ }^{30}$.W cenie, jak pisał już Perec, jest „działanie, wielkie plany, entuzjazm”, ,człowiek zmierzający do przodu, człowiek ze wzrokiem utkwionym w horyzont, człowiek patrzący prosto przed siebie" ${ }^{\text {"31 }}$. Nie bez powodu jednak Perec dodaje zaraz, że cechy te „wy ty c zają nazbyt świetlisty szlak nazbyt modelowej egzystencji [wyróż. - P.J.]"32.

Pełne uwłasnowolnienie, autodeterminacja mają swoją cenę. Przedsiębiorca-samego-siebie (ów aktywista z przymusu, jak go określa Bauman) dąży do wytworzenia wartości dodanej z pełną odpowiedzialnością za swoje decyzje, inwestycje. Jego kapitał składa się z wrodzonych predyspozycji, ale nade wszystko umiejętności, które nabył w efekcie inwestycji (począwszy od wczesnej edukacji i szkoleń, a skończywszy na odżywianiu, zdrowym stylu życia etc.). Jeśli mu się nie wiedzie, jeśli ponosi porażkę, odpowiedzialność za nią ponosi wyłącznie on sam. Winne nie są czynniki strukturalne, społeczne, polityczne, lecz indywidualne. Winne - uściślijmy - są nasze własne, złe metody zarządzania sobą. To więc, co wcześniej podlegało społecznej odpowiedzialności, staje się sprawą osobistego zabezpieczenia. Podmiot osiągnięć zostaje porzucony "na opustoszałej trasie odwrotu państwa”"33. W efekcie, jak trafnie pisze Bauman, „strach przed piętnem nieprzestrzegania zasad", typowy dla społeczeństw dyscypliny, zostaje wyparty przez obawę, że jest się niedoskonałym ${ }^{34}$. Dyskurs niedopasowania, właściwy dla kultury organizacyjnej, ustępuje dyskursowi nieadekwatności, w którym

C. Cenderström, A. Spicer Pętla..., s. 26.

A. Szarecki Kapitalizm somatyczny...

Odnoszę się tu typologii Luca Boltanskiego i Eve Chiapello Le nouvel esprit du capitalisme, Gallimard, Paris 1999.

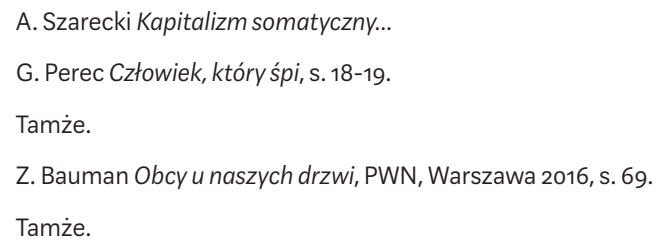


„sukces bądź porażka zależą od tego,jakim człowiekiem się jest. P r y w a t n e tożsamości zostały w ten sposób uczynione widzialnymi i rozliczanymi, a życie jednostki nierozróżnialne od kapitału [wyróż. - P.J.]"35.

Ci, którzy nie są w stanie sprostać nadmiernie wyśrubowanym „standardom", muszą w ich obliczu doświadczyć niekorzystnych dla siebie porównań. Stają się, pisze Bauman,

ofiarami samowyzysku, samozadręczania i samowyczerpania. Są zarówno ofiarami, jak i sprawcami swojej porażki oraz depresji [...]. Za niepowodzenia oraz upokorzenia, których doświadczają, winią swoją niedoskonałość, odzierającą ich z resztek szacunku do samego siebie. ${ }^{36}$

Depresja, powiada Chul-Han (a za nim Bauman), jest podstawową chorobą społeczeństwa osiągnięć, ciemną stroną - pisze z kolei Mark Fisher - „kultury przedsiębiorczości, tym, co wydarza się, gdy «magiczny woluntaryzm» dociera do swych granic"37. Dodajmy, że imperatywy produktywności, dominacja bardzo restrykcyjnych wzorców sukcesu, wraz ze znikomym sprawstwem (faktem, że nie wszyscy mają dziś potrzebne środki, by odnieść sukces), może wyzwalać także radykalne gesty. Jak powiada bohater opowiadania Fleur Jaeggy: „konieczność odniesienia sukcesu w życiu to pętla zaciskająca się na szyi. Nic innego, jak tylko pętla czekająca na wisielca"38.

W sile i odwadze, przebojowości i motywacji nie ma, rzecz jasna, niczego złego. Źle dzieje się wówczas, gdy stają się one standardem, niemal ideologią, a nieumiejętność adaptacji jest poddana stygmatyzacji. Gdy ci, którzy odbiegają od opresyjnych wzorców, są demonizowani, określani jako leniwi, słabi, pozbawieni woli. Gdy na tych, którzy nie umieją lub nie chcą się do nich dostosować, patrzy się z niechęcią lub odrazą ("musiałem zacząć nienawidzić brata”, B, s. 35), „wahałem się pomiędzy wstrętem a współczuciem”, B, s. 47). Bärfuss opowiada nam o tym poprzez system ukrytych, łączących oba teksty pomostów i subtelnych przecięć. Weźmy kilka z nich: torbacz w oczach

A. Szarecki Kapitalizm somatyczny..., s. 323.

Tamże, s. 65.

M. Fisher Why mental health is a political issue, "The Guardian" https://www.theguardian.com/ commentisfree/2012/jul/16/mental-health-political-issue (27.03.2018).

F. Jaeggy Jestem bratem NN, przeł. M. Woźniak, Noir Sur Blanc, Kraków 2018, s. 12. 
kolonizatorów budzi politowanie, brat w oczach narratora nienawiść i wstręt. Koala obdzierany jest z futra, brat z resztek godności i szacunku do siebie (z ludzkiej skóry).Tu kwestionowana jest zasada egzystencji koali, tam forma życia niefunkcjonalna wobec nowego porządku. Koloniści zastępują nazbyt pasywne istoty „efektami hodowli cywilizacyjnych” (K, s.140), neoliberalizm implementuje nowe (opresyjne) wzorce podmiotowe.

W pewnym momencie narrator powiada, że istoty „będące emanacją lenistwa znoszono jedynie w niewielkiej liczbie w ogrodach zoologicznych i w rezerwatach przyrody" (K, s. 144) lub jako zniekształcone do ludzkiej postaci, pragnącej przygód, poznawania świata, prowadzenia życia. Bärfuss czyni tu aluzję do naszych społeczeństw, nie akceptujących tych, którzy (jak jego brat) wybierają pasywność jako zasadę egzystencji. Ci, którzy nie chcą lub nie potrafią sprostać (wyśrubowanym) standardom i (opresyjnym) modelom zachowań, którzy odrzucają reguły kapitalistycznej gry, są również izolowani i poddawani działaniom naprawczym (przywracającym im „ludzką" postać). W tym paradygmacie akcent przesunięty jest na niedostosowanie do środowiska, a nie na jego toksyczność, na nieadekwatność, a nie na nadludzkie żądania. Obarczone winą jest niedotrenowane, nie dość odporne ja, nie zaś środowisko, które „śrubuje” oczekiwania aż do granic możliwości. Leczenia wymagają jednostki, a nie środowisko, w którym działają, ofiary rozpaczy, a nie mechanizm, który ją wyzwala.

Osoby takie jak brat pisarza - nie posiadając dyskursywnych zasobów, by stawić opór, internalizując ideologiczne i represyjne cele systemu - łatwo mogą znaleźć się w stanie wojny ze sobą. Ta zaś - jak wspomnieliśmy może skończyć się działaniem naprawczym (terapią). Ofiara może dokonać „rachunku sumienia” i wrócić (na powrót do wspólnoty) z mocnym postanowieniem poprawy. Wtrącona w siebie (oślepiona ja, które wypełnia całe pole widzenia) może jednak próbować wymknąć się sobie - uciec nieodwołalnie przed sobą.

Mimo że czytelnik nie ma pełnego wglądu w kulisy gestu bohatera Bärfussa, staje się jasne, że brat jest ofiarą kultury skolonizowanej przez opresywne standardy i wzorce. Choć prowadzi życie na bocznym torze, z dala od „zgiełku”, ostatecznie okazuje się, że nie jest w stanie dłużej go wieść, skoro wszystko podpowiada mu nieustannie, że (w tym społeczeństwie) przegrał; że jako przedsiębiorca-samego-siebie definitywnie splajtował. To właśnie ma na myśli narrator, kiedy pisze. „O moim bracie będzie się odtąd opowiadać tylko te historie, które potwierdzały jego własną odpowiedzialność, dowodziły, że jego śmierć była konsekwencją fałszywego 
myślenia, fałszywej postawy życiowej" (K, s. 48). Zwróćmy uwagę, że każdy z bohaterów ewokowanych tu pomocniczo tekstów (Foster Wallace, Houellebecq, Shuty) popełnia samobójstwo albo się o nie ociera (Perec) ${ }^{39}$. Wszyscy za sprawą tego samego mechanizmu czują się w pewnym momencie życia przegrani ${ }^{40}$ : bohaterka Samobójstwa jako formy prezentu zadręcza się i nienawidzi, Perec (a także jego bohater) pisze o sobie jako „nieudaczniku” („jestem bytem nieproduktywnym i niepożądanym"41), zaś bohater Houellebecqa wyznaje wprost: „Porażka, zawsze porażka. Jedynie samobójstwo mieni się blaskiem"42.

\section{Tina?}

Zdrowy rozsądek, który uosabia zrazu narrator, podpowiada, że tryb życia brata, jego zasada egzystencji musiały prędzej czy później doprowadzić do anihilacji. „Nie żeby zasłużył na tę śmierć - ale była ona logiczną konsekwencją jego zachowania" (B, 37-38). W tym ujęciu samobójstwo byłoby „zwieńczeniem długiego procesu, którego źródeł powinniśmy szukać w samej jednostce, w jej «wadliwej konstrukcji ontologicznej»"43. Takie zdroworozsądkowe formy myślenia utrwala - jak twierdzę - wyabstrahowanie cierpienia z uwarunkowań systemowych. Raz przeniesione za medyczny parawan, znika z pola widzenia, stępiając naszą wrażliwość, nie poruszając sumień. Wielu badaczy i badaczek nie pozostawia złudzeń, że obecny neoliberalny konsensus (z jego ewangelią indywidualizmu) wzmacniają dziś nauki medyczne. Obecny medyczny paradygmat „spełnia często funkcję nadzorcy i strażnika kulturowego status quo, nie zaś agenta przezeń pokrzywdzonych i odsuniętych na margines" ${ }^{44}$. W Koali echem tej krytyki są „sumienne” raporty

39 W przypadku Człowieka, który śpi Perec rozważał początkowo właśnie taki finał, zob. Georges Perec. En dialogue avec l'époque et autres enretiens 1965-1981, ed. by D. Bertelli, M. Ribière, Joseph K., 2001. Sam Perec także próbował targnąć się na życie, D. Bellos Une vie dans les mots. Biographie, Éditions du Seuil, Paris 1994, S. 171

40 Bohater Houellbecqa mówi, że "dziś niemal każdy z nas w pewnym momencie życia czuje się przegrany", Poszerzenie pola walki, przeł. E. Wieleżyńska, W.A.B., Warszawa 2015, s. 34).

41 D. Bellos Une vie dans les mots..., s. 170.

42 M. Houellebecq Poszerzenie pola walki, s. 140.

44 T. Stawiszyński Czego uczy depresja, http://krytykapolityczna.pl/kraj/stawiszynski-czego-uczy-depresja/?fb_comment_id=526133860826412_790044131102049 (27.03.2018). 
neurologów, które w żaden sposób nie zbliżają bohatera do poszukiwanej odpowiedzi. Ich „kompendia” dokumentują „jedynie te samobójstwa, które wydawały się im egzemplaryczne" (K, s. 33). Dokonany wybór, czytamy, rzuca „cień na [ich] naukową rzetelność” (K, tamże). Jak pisze Carl Walker, niedocenianie uwarunkowań strukturalnych zaburzeń utrwala tylko ich moc: „For as long as the mental health industry resides within a framework that speaks the language of self-hood, and minimizes the importance of political and economic forces, it will continue to contribute to the problems that it has been charged with healing"45.

Co więc można, a raczej należy zrobić? Jak stawić opór mogą cierpiący, a priori obsadzani w roli sprawców swego nieszczęścia. Jak mogą odrzucić ów werdykt, skoro nie znają innego? „Najwyższy czas, by winę umieszczono gdzie indziej", powiada Mark Fisher ${ }^{\mathbf{4 6}}$. Jednak, by tak się stało, by dało się przenieść winę (ze złego „zarządzania sobą" na złe zarządzanie społeczeństwem), potrzebny jest demontaż „globalnej wulgaty” (Bourdieu), rozbrojenie dominujących mitów, które stały się zdroworozsądkową prawdą. Neoliberalizm tak dalece skolonizował nasze myślenie (narzucając się światu pod pozornie ahistoryczną maską), że stał się przeźroczysty, a uległość wobec logiki rynkowej (także po lewej stronie) tak powszechna, że niemal niezauważalna ${ }^{47}$. Hegemonia, którą udało się wywalczyć głównie w zmaganiach dyskursywnych, sprawiła, że - jak powiada Jameson - łatwiej dziś wyobrazić sobie koniec życia na ziemi niż koniec kapitalizmu ${ }^{\mathbf{4 8}}$. To, co należy czynić, powiada Amerykanin, to głośno protestować przeciwko tezie, że rynek leży w ludzkiej naturze ${ }^{49}$, nieustająco podkreślać jego hegemoniczność, denaturalizować schematy myśli neoliberalnej. Nic bowiem nie daje większej władzy

„Tak długo, jak przemysł zdrowia psychicznego znajduje się w strukturalnych ramach, które mówią językiem indywidualizmu i minimalizują znaczenie sił politycznych i ekonomicznych, będzie on nadal przyczyniał się do problemów, które miał usuwać" - przekł. P.J. C. Walker Depression and Globalization..., s. 180.

M. Fisher Why mental health...

47 F. Jameson Postmodernizm, czyli logika kulturowa późnego kapitalizmu, przeł. M. Płaza, Wydawnictwo UJ, Kraków 2011, s. 268.

48 "It seems to be easier for us today to imagine the thoroughgoing deterioration of the earth and of nature than the breakdown of late capitalism". F. Jameson The Seeds of Time, Columbia University Presss, New York 1994. XII. 
niż możliwość działania bezimiennie, z ukrycia ${ }^{50}$. To, czego nie widać, nie da się ani krytykować, ani zmieniaćc ${ }^{51}$.

Nasze emancypacyjne działania, mówi Fisher, muszą niszczyć pozór „naturalnego porządku rzeczy”, ujawniać przygodność tego, co ogłasza się jako nieuchronne i konieczne, i sprawić, by to, co niemożliwe, zaczęło wydawać się możliwe do osiągnięcia ${ }^{52}$. Jak to czynić? Wierzę, podobnie jak Bärfuss, że jednym z narzędzi oporu i emancypacji może być (już jest) literatura.

\section{"C'est la guerre"}

Pisząc o polskiej powieści wyrażającej niezgodę na kapitalizm, Przemysław Czapliński powiadał, że robiła to językiem wątpliwym („światopoglądowo miałkim, niekiedy obskuranckim, czasem nacjonalistyczym"), ale jednak robiła to, nie pozwalając tym samym „by nowa ekonomia nabierała charakteru oczywistości ustrojowej, bo wtedy ofiary transformacji przekształcały się w ofiary własnej nieudolności, bądź po prostu w konieczne koszta wspólnego marszu ku lepszej przyszłości"s3. Istotnie, dyskursywny oręż daje szansę wypowiedzenia krzywdy, której inni nie potrafią rozpoznać, obrony przed przypisaniem nam winy. Dla innych bywa także odciążeniem. „To nie przypadek, pisał Fisher w Ghosts of My Life, że moja (jak dotąd udana) ucieczka przed depresją zbiegła się z pewną eksternalizacją negatywności: problemem nie byłem (tylko) ja, ale otaczająca mnie kultura"54. Ów ruch eksternalizacji, dobrze obrazują słowa bohatera debiutu Houellebecqa, gdzie godzi się on na określenie „depresja”, ale w takim oto znaczeniu: „Nie żebym czuł się bardzo nisko: to raczej otaczający świat wydaje mi się bardzo wysoko [wyróż. - P.J.]"55. W Capitalist Realism brytyjski teoretyk pisze wprost:

50 G. Monbiot Neoliberalism - the ideology at the root of all our problems, "The Guardian", https:// www.theguardian.com/books/2016/apr/15/neoliberalism-ideology-problem-george-monbiot (28.03.2018), zob. też T. Markiewka /ęzyk neoliberalizmu, Wydawnictwo UMK, Toruń 2018, s. 256.

51 Tamże, s. 258.

52 M. Fisher Capitalist Realism..., s. 23.

53 P. Czapliński Polska do wymiany: późna nowoczesność i nasze wielkie narracje, Wydawnictwo Literackie, Kraków 2009.

M. Fisher Ghosts of My Life: Writings on Depression, Hauntology and Lost Futures"

55 M. Houellebecq Poszerzenie pola walki, s. 145. 
Musimy przekształcić powszechne problemy zdrowia psychicznego ze zmedykalizowanych form w efektywne antagonizmy. Zaburzenia afektywne to formy opanowanego niezadowolenia [captured discontent]. Ta niechęć może i musi być skierowana na zewnątrz, skierowana ku prawdziwej przyczynie - Kapitałowi. ${ }^{56}$

To właśnie zdaje się czynić Bärfuss. Jego narrator ostatecznie przenosi źródło problemu (i radykalnego cierpienia) z wnętrza podmiotu na zewnętrzne realia, w których żyjemy. Realia, którymi, jak powiedział dziennikarzowi, „rządzi dziś już tylko jedno kryterium - ekonomiczne"57. Nic innego nie mówi jego powieściowe alter ego

Zacząłem liczyć jakie miałem jeszcze perspektywy, co już dostałem. I zauważyłem, jak łatwo przychodziły mi te kalkulacje. Nie byłem jedynym, który porównywał, mierzył i zliczał. Nie tylko moje umiejętności księgowe były wysoko rozwinięte, dotyczyło to także moich bliźnich. Je dy n a umiejętność niezbędna do życia polegała na poprawnym kalkulowaniu ryzyka i możliwego zysku z inwes ty cji [wyróż. - P.J.].Ile coś mogło kosztować i ile mogło przynieść. Wystarczało, jeśli według tego człowiek kierował własnym życiem. (K, s. 34)

Bohater z tomu Czym jest człowiek Davida Szalay'a, gdzie sens każdego wydarzenia odczytywany jest za pomocą liczb, powiada niemal dokładnie to samo. „Uświadomienie sobie prawdziwej prostoty tego wszystkiego jest naprawdę ważne" ${ }^{58}$. Ostatecznie, myśli, nic innego się nie liczy. „C'est la guerre", „C'est la guerre" powtarza raz za razem ${ }^{59}$. W obu prozach interakcje społeczne zaczynają być modelowane jak rywalizacja. W Koali walka okazuje się jedyną zasadą: ,jedna wielka rebelia, wszyscy w walce przeciwko wszystkim" (K, s. 35). Dla Pierre'a Bourdieu podważenie zbiorowych struktur, które mogłyby zakłócić czystą logikę rynku, stanowiło istotę neoliberalizmu. Osłabienie lub wręcz zniesienie logiki solidarności oznaczało zaś właśnie

56 Tamże, s. 80.

57 Es ist Zeit, die Dinge beim Namen zu nennen, "Schweiz am Sonntag" https://www.schweizamwochenende.ch/nachrichten/es-ist-zeit-die-dinge-beim-namen-zu-nennen-131063708 (19.03.2018).

D. Szalay Czym jest człowiek, przeł. J. Polak, W.A.B., Warszawa 2018, s. 236.

59 Tamże. 
walkę - „wszystkich przeciwko wszystkim na wszystkich szczeblach hierarchii”60. Tak właśnie ujął to w swym debiucie Houellebecq: „liberalizm ekonomiczny to poszerzenie walki, która toczy się w każdym wieku i wszystkich klasach społecznych"61. W powieściowym świecie (a raczej: światach) Bärfussa rządzi jedno prawo - prawo do maksymalnego zysku. Brat i koala wydają się równie bezwartościowi, bo nieużyci. Wszystko co w nich inne, nie poddające się logice rynku, zostaje brutalnie wyparte. Jedyny (choć marny) zysk, jaki zwierzę może zaoferować, to dające się spieniężyć futro, które ściąga się przez uszy. Brat w oczach narratora jest równie nieużyty, jego egzystencja więc zaprzepaszczona. „Żadnego majątku” wypomni mu, by dodać, że być może jego życie „nie zasługiwało na nic innego niż ciśnięcie do śmieci” (K, s. 35).

\section{Koala czyli o innej możliwości egzystencji}

Szwajcar nie zostawia jednak czytelnika bez nadziei, jak robi to np. Houellebecq $^{62}$.W świecie Koali możliwa jest zmiana. W powieści dokonuje się ona za pomocą imaginacji, innego rodzaju języka, który włącza w obszar widzialnego to, co zostało z niego wykluczone. Źródło problemu i winy - jak w postulacie Fishera - zostaje przemieszczone. Choć narrator przyzna, że jego brat poniósł porażkę („była niezaprzeczalna”, K, s. 49), to powie przecież, iż „nie przegrał walki z samym sobą, ze swoimi wadami, lecz z większym, potężniejszym i przede wszystkim starszym przeciwnikiem" (K, s. 49-50). Ta powolna rewizualizacja dokonuje się w powieści za sprawą totemu. To on wywołuje ukłucie serca u bohatera. Razem z gestem brata paraliżuje go, wczepia w jego codzienność jak nigdy nic innego (K, s. 37). Kiedy narrator „otworzy na niego podwoje", zwierzę zacznie pojawiać się wszędzie (K, s. 52). Istota z owłosionymi uszyma, stoicka, „pukała, bo chciała mi coś powiedzieć, nie wiedziałem co, nie dawała żadnych wskazówek, po prostu była" (K, s. 37). Mogła pojawić się w każdej chwili, np. o świcie, przy kuchennym stole - para guzikowatych oczu pływających w kawie. Przy wejściu do baru w pobliżu. Istota niema, wydająca się raczej wysyłać obrazy, np. „położony w oddali na wschodzie łańcuch górski, połyskujący niebieskawo o zmierzchu" (tamże), jakby coś odsłaniająca

60 P. Bourdieu L'essence du néolibéralisme.

61 M. Houellebecq Poszerzenie pola walki, s. 105. O rozpadzie więzi społecznych i wspólnoty w neoliberalizmie piszę w osobnym miejscu.

62 Zob. o tym C. Sweeney Michel Houellebecq and the Literature of Despair, Bloomsbury Academic, London 2013. 
(dotąd zakrytego), jakby coś uwalniająca (dotąd zablokowanego). Co? Być może samo życie uwięzione dotąd przez mityczny porządek.

A zatem - koala jako rodzaj filtra, przez który jawi się rzeczywistość (i która teraz zaczyna opowiadać o czymś innym), nowe okno, z którego co innego widać. Koala, którego myśleć można razem z bratem, ale także osobno, jako odpadłą, czekającą na obsadzenie, formę życia. „Wczepiony”, totem nicuje potoczne i przeżyte percepcje bohatera, a to znaczy - pruje rzeczywistość i stawia do pionu, jakby od nowa. Tak, że narrator zapyta naraz: „czy zaraziłem się już chorobą brata, czy jego przesłanie zaatakowało moje myślenie". A może, zapytuje, „to była kwestia moich oczu?”, może „po raz pierwszy spojrzałem na świat uczciwie" (K, s. 34).

Narrator, „otwierając na niego podwoje”, pozwala na zarażenie się przez obcą formę. Otwarcie na inność tego, co mniejsze wyzwala ruch wywłaszczania z zakrzepłej formy, z zastygłego kształtu bycia, wyzwolenie się z pospolitych uczuć i opinii (będących na usługach określonego stylu życia), z pragnień i aspiracji (poddanych uprzedniemu formatowaniu przez kapitalistyczną kulturę). Odtąd nic nie jest już jasne, np. to czy to właśnie nie owi "prawi” (tacy jak on), żyjący obiegowymi cnotami (ambicją i aktywnością, kreatywnością i mobilnością) nie pójdą najszybciej w zapomnienie. Na ogół sądzi się, że to oni zostaną, ich dzieła wyniosą ich poza czas, wyrwą śmierci, zapomnieniu. A jednak, czytamy, spoglądając na świat zbudowany z ich dzieł i czynów, nie znajduje się „wielu argumentów, które przemawiały za ambicją i pilnością” (K, s. 49). Nie da się wykluczyć, że świat „byłby przyjemniejszy, gdyby więcej ludzi kierowało się zasadami mojego brata", pragnąc dla siebie tylko tego, co najbardziej konieczne, na własność mając jedynie to, czego spisanie zajęłoby półtorej strony i co w ciągu godziny mogłoby zostać rozdzielone między przyjaciół (K, s. 49). W końcu narrator pojmie, że on sam jest jednym z owych prawych, że pełni rolę "neoliberalnego agenta" ${ }^{\text {, }}$, kolejnego wcielenia kolonizatora, plantatora tytoniu, który, owszem, zarządza armią niewolników, lecz tak naprawdę sam jest sługą. Nosi kajdany, jak jego poddani, choć te nie są zrobione ze stali, lecz z papieru, i „noszą pieczęć Bank of England” (K, s. 75). Powie przecież: „na służbie, w niewoli”, ,tak właśnie żyliśmy, ja tak właśnie żyłem. Po za s t w o r z e n i e m [wyróż. -P.J.]" (K, s. 146;).

63 Określenie Philipa Mirowskiego, które podaję za: C. Cenderström, A. Spicer Pętla..., s. 119-120. (Neoliberalny agent to samozwańczy pragmatysta, który „zrozumiał, że nie jest jedynie pracownikiem czy studentem, lecz funkcjonuje równocześnie jako produkt na sprzedaż, chodząca reklama, twórca swojego życiorysu, biograf racjonalnych decyzji, jako impresario swoich możliwości"). 
Jeśli każdy porządek władzy zakłada i reprodukuje określone formy podmiotowości, to gest odmowy jest rodzajem odpodmiotowienia, „zakwestionowaniem form życia funkcjonalnych wobec owego porządku"64. Pół-brat sytuując się poza porządkiem społecznych ról i stylów życia, podał w wątpliwość dominujące wzorce podmiotowe: głowy rodziny, konsumenta i przedsiębiorcy-samego-siebie. Jego gest został jednak spacyfikowany, a on stracił w sobie suwerenność, internalizując (najwyraźniej) ideologiczne i represyjne cele, które skłóciły go z samym sobą i zacisnęły pętlę wokół szyi. Rozbrojony niczym zapalny materiał, którego wybuch mógł wstrząsnąć panującym porządkiem, został pochowany poza murami wspólnoty. Nie było dla niego miejsca w historii ani wieczności. „Wichrzyciela”, jednego z tych, o których „nie można było myśleć, nie zarażając się [...] pozostawianą przez nich turbulencją", nie mógł przyjąć żaden cmentarz (K, s. 153). Jego świecki pogrzeb umilił utwór o człowieku, „który jaśniał niegdyś jak słońce”, lecz „teraz jego oczy stały się [...] czarnymi dziurami" (K, s. 151) ${ }^{65}$. Prochy zostały rozrzucone w jeziorze, kilka miesięcy później, w zimny marcowy dzień.

\section{Tata ${ }^{66}$ albo o (de)formującym potencjale fikcji}

Nie sposób prześlepić ostatni akapit powieści. Oto narrator wraca ze stypy, wsiada do samochodu i kieruje się do domu, by co rychlej zabrać się do pracy. Słowa te są rozmyślnie dwuznaczne. Można je czytać więc tak: oto brat zasiadał do pracy, ponieważ wstrząs, którego zaznał, nie był głęboki, niczego w nim nie dokonał, nie zmienił jego „parametrów egzystencjalnych"67. Można też uznać, że zmienił istotnie, i dlatego właśnie zaczął pracę, a to znaczy pisanie. Być może jednak - przy czym drugie nie wyklucza trzeciego - jest tak, że odpowiedź tę każdy musi znaleźć na własną rękę.

Znamienny jest także opis wspomnianej stypy. Przybyło na nią tuzin osób. Nie odbyła się jednak, jak czytamy, w restauracji, „miała w sobie coś ze spisku” (,jakby trzeba było się ukrywać, bo trzymało się z samobójcą”, K, s. 154).

64 M. Herer Bartleby i jego bracia albo o politycznej sztuce odmowy, http://machinamysli.org/author/michal-herer/ (12.03.2018).

65 To aluzja do utworu Pink Floydów i Syda Barretta, którego historia w pewnym zakresie jest analogiczna do historii brata pisarza.

66 Akronim („There are thousands of alternatives!”), ukuty w nawiązaniu i opozycji do thatcherowskiej TINY.

67 By posłużyć się poręcznym określeniem Grzegorza Jankowicza. 
Zamiast gospody wybrano dom skautów, pomieszczenie wychodzące na las. Wybrano „świątynię totemu”, który, jak powiada narrator, „doprowadził nas do tego miejsca, żeby opowiedzieć inną historię, in ną możliwo ść e g zy s t e n c j i [wyróż. P.J.]" (K, s. 156-157). Narrator zasiada w domu skautów, zawiązując (pośmiertną) braterską wspólnotę spisku. Na czym miałby jednak polegać (w jego przypadku)? I czym w istocie jest „świątynia totemu”? Jeśli, jak pamiętamy, to za sprawą imaginacji udało się zrekonstruować opowieść, „na temat której brak było abstrakcyjnych pojęć” (K, s. 51), to można zasadnie przyjąć, że świątynią jest właśnie imaginacja i fikcja, której w udziale przypada atrybut spisku.

Powieść Szwajcara nie jest tylko opowieścią o (zamorskiej i neoliberalnej) kolonizacji, o narastającym zekonomizowaniu wszystkich kontekstów życia człowieka, o kulturze przedsiębiorczości, która niszczy wszystko na swojej drodze. Jej tematem jest coś znacznie więcej - samo pisanie, a ujmując rzecz ściśle: jego stawka. Co daje nam literatura? Jakie pytania pozwala postawić? I jakie rozwiązania nam podsuwa? Według Bärfussa pisarz, niczym optyk, musi bezustannie regulować ostrość widzenia: by dostrzec to, czego wcześniej nie zauważaliśmy (a więc - o czym nie mogliśmy myśleć), by z prześlepionego czynić nowy rodzaj widzenia. Literatura, jak w formule Paula Klee, nie ma reprodukować widzialnego, lecz czynić widocznym, a także - dodajmy - odczuwalnym (w perceptach, afektach) coś, co nie jest odczuwalne na gruncie zwykłej percepcji ${ }^{68}$.

Dzieło Szwajcara w ruch wprawia „haniebność zaoferowanych możliwości życia" (G. Deleuze), ideałów i mniemań naszej epoki ${ }^{69}$. Rzeczą powieści jest walka przeciw nim, nie zaś wymyślanie kojących historii, rozkładanie ochronnego parasola bon sens. Bärfuss tworzy literaturę niepokoju, taką, o jakiej pisał w liście do Oskara Pollaka Franz Kafka i o jakiej mówił Emil Cioran

Potrzebujemy książek, które wpływają na nas jak katastrofa, które głęboko nas zasmucają, jak śmierć kogoś, kogo kochaliśmy bardziej niż siebie samych, jak wygnanie go do lasu z dala od kogokolwiek, jak samobójstwo. Książka musi być siekierą dla zamarzniętego morza wewnątrz nas. ${ }^{\mathbf{7 0}}$

68 M. Herer Gilles Deleuze. Struktury - maszyny - kreacje, Universitas, Kraków 2006, s. 215-216.

69 G. Deleuze, F. Guattari Co to jest filozofia?, przeł. P. Pieniążek, słowo/obraz terytoria, Gdańsk 2000, S. 122. 
„Książka, pisze z kolei Cioran, która pozostawia czytelnika takim, jakim był

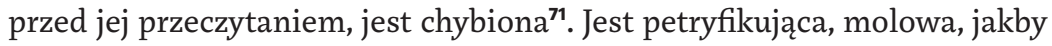
powiedział Deleuze, czyni stawanie się reaktywnym.

Uważam, że powinno się w ogóle czytać tylko takie książki, które człowieka gryzą i dźgają. Gdy książka, którą czytamy, nie budzi nas uderzeniem pięści w łeb, to po cóż ją czytamy? ${ }^{72}$

Książka powinna gmerać w ranach, nawet je jątrzyć. Książka powinna być niebezpieczeństwem [...] naprawdę być raną, [...] musi w taki lub inny sposób zmieniać życie czytelnika. Kiedy piszę książkę, chodzi mi o przebudzenie kogoś, o schłostanie go. ${ }^{73}$

Sam autor 100 dni w eseju Der Ort der Dichtung o Heinrichu von Kleiście napisał, że pisarze stwarzają "przestrzenie, w których oni sami i my wszyscy możemy się zmieniać, w wyobraźni, a czasem nawet w rzeczywistości ${ }^{74 ”}$. Bärfuss jest doskonale świadom, że to właśnie w (de)formującym żywiole imaginacji i fikcji („bardziej żywej od samego życia”75) kryje się szansa. Na co? $\mathrm{Na}$ - jakby powiedział Fisher - wydrążenie dziury w kapitalistycznym realizmie, otaczającym nas niczym ostateczny myślowy horyzont. Szwajcar, co istotne, nie robi niczego w trybie otwartej walki, jawnej krytyki, prymitywnej pedagogiki. Jego Koala nie jest zbitką mniemań, ale kompozycją wrażeń, rozbudzającą przytomność umysłu. Efekt uzyskuje m.in. poprzez montaż heterogenicznych treści, kreację przestrzeni, w której coś - dotąd blokowane, zakorkowane - zaczyna migotać i wkrada się, zmieniając nasze reguły działania. Za każdym razem pierwszoplanowa jest nie destrukcja, lecz twórcze działanie, które wtórnie burzy (pospolite emocje), nicuje (przeżyte percepcje) i wybija (z nawyków myślowych). Doprowadza do ekstazy ciała, intelektu, zmysłów i rozumu. U Bärfussa zmiana nie jest możliwa za pomocą innych narzędzi - tylko imaginacji i fikcji. „Porażkę przyszłości” da się odwrócić

71

E. Cioran Rozmowy, przeł. I. Kania, Aletheia, Warszawa 2018, s. 18.

Tamże, s. 26.

Tamże.

"Schaffen keine Orte, sie schaffen Räume, in denen sie sich selbst und wir alle uns verändern können, in der Vorstellung, und manchmal sogar in der Wirklichkeit". A. Bartl Kleist und Ich. Eine Analyse der 15 Kleist-Preis-Reden 2000 bis 2014, "Kleist-Jahrbuch 2016”, s. 33.

M. Herer Gilles Deleuze..., s. 185. 
tylko za sprawą zderzenia tego, co jawi się jako permanentne, niewywrotne i niezmienne (systemu) z tym, co nieograniczone, otchłanne i nieskończone w swej potencjalności (fikcji).

W Koali czytelnik zostaje wciągnięty do gry, stajacy się wraz z narratorem. Jak on, raz po raz wpada w pułapki, które pisarz zasadza na jego zdrowy rozsądek. Wystawiający na próbę ruch gry, odkształca, rozszczepia, przemieszcza jego percepcyjne ramy, tak że czytelnik opuszcza ją jako ktoś inny - rozłożony i na nowo złożony, postawiony, ulepiony - nowy człowiek, nowy podmiot. Zmiana, której nie doczekał Mark Fisher, zdaje się mówić Bärfuss, jest możliwa; przejście od sytuacji, w której nic nie jest możliwie, do stanu, w którym nagle wszystko staje się możliwie ${ }^{76}$. Szwajcar sugeruje, że „najdrobniejszym wydarzaniem, które może wydrążyć dziurę"77, może być (inna) opowieść (zdolna dokonać rozbiórki hegemonicznego języka ekonomii). Inna narracja, która obejmie kolejne połacie świata i przykryje go zupełnie nowym gatunkiem języka. Tak, że w końcu niemożliwe stanie się oddzielenie świata od dzieła, które trwać będą już odtąd „zawsze jako kompatybilne i połączone niby w kłączu, światy realne"78.

\section{* * * *}

Depresyjne zakleszczenie jest radykalnym cierpieniem i realnym zagrożeniem dla życia. Ci, którzy doświadczają jego rozwoju, wzmagania, jego kulminacji, oczekują pomocy. Ta jednak nie wyczerpuje się w łatwej medykalizacji (co widać doskonale po bezradności lekarzy wobec nawrotów depresji). Dziś widać wyraźne, że potrzebne jest przejście od patologizacji depresji do jej upolitycznienia. Zamiast nadmiernie i fałszywie skupiać się nad naszymi chorobami, należałoby raczej przyjrzeć się chorobom naszego świata ${ }^{79}$, naszej - jak pisze Ann Cvetkovic - chorej kulturze ${ }^{\mathbf{8 0}}$. Taki właśnie ruch wykonuje Bärfuss. Jego powieść zaczyna się próbą zdiagnozowania brata, a kończy

76 M. Fisher Capitalist Realism, s. 80.

77 Tamże.

78 G. Deleuze, F. Guattari Kafka. Ku literaturze mniejszej, Eperons-Ostrogi, Kraków 2016, s. 330.

79 C. Cenderström, A. Spicer Pętla..., s. 154.

80 A. Cvetkovic Depression: a Public Feeling, Duke University Press 2012; I. Boruszkowska Defekty. Literackie Auto/pato/grafie, Wydawnictwo UJ, Kraków 2016. Za zwrócenie uwagi na prace Cvetkovic i inspirujące rozmowy dziękuję w tym miejscu Iwonie Boruszkowskiej. 
diagnozą kultury. Pisarz okazuje się diagnostą, a koala nie pacjentem, lecz lekarzem - „uzdrowicielem, nowym Chrystusem albo naszym bratem" ${ }^{\text {"1. }}$.

\section{Abstract}

\section{Paweł Jasnowski}

JAGIELLONIAN UNIVERSITY (CRACOW)

Neoliberal Capitalism and Depression: Some Remarks on the Margin of Lukas Bärfuss's Koala

Jasnowski explores Lukas Bärfuss's novel Koala to highlight the impact of free-market fundamentalism on mental health. He juxtaposes the diagnoses proposed by Bärfuss with theoretical works by Carl Walker and Mark Fisher, who have linked the epidemic of depression (and increased suicide rates) to the neoliberal status quo. Jasnowski also asks how to overcome the current impasse. Like Bärfuss he believes that literature can be a tool of resistance and emancipation. "The failure of the future,"Bärfuss argues, can only be reversed through a clash of what seems permanent, fixed and unchangeable (the system) with that which is unlimited, abysmal and infinite in its potentiality (fiction).

\section{Keywords}

Lukas Bärfuss, capitalism, capitalist realism, culture of entrepreneurship, depression, Gilles Deleuze, Mark Fisher, neoliberalism, suicide

81 G. Deleuze Bartleby albo formuła, przeł. G. Jankowicz, w: H. Melville Kopista Bartleby. Historia z Wall Street, przeł. A. Szostkiewicz, Sic!, Warszawa 2009, s. 104. 